\title{
THE FEELINGS OF CONSUMER GUILT: A PHENOMENOLOGICAL EXPLORATION
}

\author{
Ayla Özhan Dedeoğlư ${ }^{1}$ İpek Kazançoğlu ${ }^{2}$ \\ Department of Marketing, Faculty of Economics and Administrative Sciences, \\ Ege University, Bornova, Izmir, Turkey \\ E-mails: ${ }^{1}$ ayla.dedeoglu@ege.edu.tr; ${ }^{2}$ ipek.savasci@ege.edu.tr
}

Received 12 October 2009; accepted 19 May 2010

\begin{abstract}
Guilt, a discomforting, yet widespread emotion, has been frequently exploited by advertisers. Despite all of the great deal of research effort, there remains a dearth of research that examines the dimensions of consumer guilt by providing a more complete understanding. The present study represents an attempt to develop a phenomenological account of consumer guilt and broaden the understanding of the dimensions and dynamics of consumer guilt grounded in consumers' lived experiences by using in-depth interviews and projective data. Regarding this, a thorough analysis revealed the existence of five dimensions of consumer guilt, namely, hesitation, sadness, reluctance to spend, regret and self-blame. Consumer guilt is felt due to transgressions, self-control failures and indulgence in hedonistic desires. The findings show that guilt feelings are found to be cyclic, short-lived and superficial and mostly arise as a result of good and bad actions but not always of right versus wrong actions. In the consumption society, guilt is attached to new concerns brought about by cultural drift.
\end{abstract}

Keywords: consumer guilt, transgressions, self-control failures, indulgence, consumer culture, regret, self-blame, sadness, hesitation.

Reference to this paper should be made as follows: Dedeoğlu, A. Ö.; Kazançoğlu, İ. 2010. The feelings of consumer guilt: a phenomenological exploration, Journal of Business Economics and Management 11(3): 462-482.

\section{Introduction}

As Miller (1995) argued, consumption has become the vanguard of history. Contemporary consumer culture, in which consumption objects and experiences play a key role in constructing a sense of self and community (Arnould and Price 2000), has been marked 'by a dialectic between asceticism (i.e., self-discipline as a moral responsibility) and the hedonic pursuit of gratification and pleasure (Thompson and Hirschman 1995)'. The individual, under the disciplinary gaze becomes his/her own agent of surveillance conforming to normative conventions (Thompson and Hirschman 1995), exerts self-control and simultaneously pursues gratification and pleasure in life. Especially, 'self-aware' consumers who are targeted by marketing practitioners through marketing communications live in paradoxes of contemporary consumer culture; through marketing communication some products are positioned as objects of desires or emancipation, yet some others refer to cultural values and norms, ideology of self-control and utilitarian consumption and appeal to guilt feelings. 
Guilt, a discomforting, yet widespread emotion, has been frequently employed by advertisers. By evoking guilt through either guilt arousing or guilt decreasing marketing communications; marketing practitioners, especially advertisers, try to influence consumer behavior (Cotte and Ritchie 2005; Soscia et al. 2008). The use of guilt appeals in marketing communications, especially in advertisements, has received considerable attention by researchers as well (e.g. Ghingold 1981; Huhmann and Brotherton 1997; Cotte et al. 2005). Findings mostly reveal positive impact of guilt on purchase behavior, especially when some conditions are fulfilled, such as a certain level of sponsor credibility and consumer perception of fairness of the ad and the advertiser's motivations (Coulter et al. 1999). Consumer guilt is found to relate to impulsivity (Puri 1996; Rook 1987; Sengupta and Zhou 2007; Virvilaite et al. 2009) and compulsive consumption (Hassay and Smith 1996; O'Guinn and Faber 1989), hedonic consumption (Kivetz and Simonson 2002; Okada 2005), desire (Belk et al. 2003; Boujbel 2008) and indulgences (Ramanathan and Williams 2007; Xu and Schwarz 2009). It is also found to influence consumers' altruistic behavior and response to charity appeals (Chang 2008; Basil et al. 2008). One can say that, in general, these studies give some results with regard to consumer guilt, but it is not their primary focus.

On the other hand, there are a few studies that mainly researched consumer guilt. Several researches studied antecedents and/or consequences of consumer guilt (Bei et al. 2007; Lin and Xia 2009), anticipated and reactive guilt and regret (Bagozzi et al. 2000; Cooke et al. 2001; Meyvis and Cooke 2007; Tsiros and Mittal 2000) and consumers' coping mechanisms with it (Dahl et al. 2005; Yi and Baumgartner 2004). These studies generally tried to conceptualize consumer guilt and/or explain consumer guilt by taking self-control failure into account (Burnett and Lunsford 1994; Chun et al. 2007; Dahl et al. 2005; Keinan and Kivetz 2008; Lin and Xia 2009). Despite all of the great deal of research effort, there remains a dearth of research that examines the dimensions of consumer guilt by providing a more complete understanding. The present study represents an attempt to develop a phenomenological account of consumer guilt and broaden the understanding of the dimensions and dynamics of consumer guilt by using in-depth interviews and projective data. Pursuing the aim to explore the construct grounded in consumers' lived experiences, the present study differs from other studies by its phenomenological approach without any prior engagement in specific propositions.

Furthermore, to our best knowledge, this is the first study on consumer guilt in Turkey, a developing, yet less affluent country. Examining consumptionscapes of Turkey, Sandikci and Ger (2002) observed plurality and difference among different consumption styles (namely, spectacularists, nationalists, Islamists and historicists) and discuss that the Turkish case may be read as a case that provides support for the notion of multiple modernities, highlighting the fact that there are multiple routes to modernity. One can also observe different consumptionscapes even in different cities of Turkey. Embracing a diverse population with various ethnic and religious backgrounds of inhabitants, Izmir, Turkey's third most populous city, is mostly known for its westernized consumptionscape. As an exemplar of westernized Turkish consumer culture, the cultural context of Izmir provides a rich source for data collection. 
In this respect, prior studies on consumer guilt and regret are reviewed first for the aim of the study. The remainder of the study is as follows. The next section gives the interpretation of findings of the current qualitative study with the frame of emotional constructs of consumer guilt, transgressions of norms, self-control failure and indulgence and hedonic consumption. Embedding the present study of consumer guilt within context of the consumer culture in Izmir, Turkey, in the last section, the findings are also discussed based on cultural transformations and diversities in consumers' experiences of feelings of guilt.

\section{Consumer Guilt}

Consumer guilt is a subjective feeling which results from one's recognition of having failed to achieve or violated (or even imagining to do so) internalized personal or social moral standards (Bonsu and Main 2006; Boujbel 2008; Watson and Spence 2007). Consumer guilt is the type of guilt that is related specifically to consumption decision situations. The feeling of guilt differs from the concept of guilt. Mosak (1987) explained that guilt is established by moral laws set by society to assure safety of life and possessions of the individual. Dahl et al. (2003) pointed that guilt feeling is correlated with a sense of self-responsibility and self-control, regardless of whether the transgression involved an act of commission or omission. Self-caused events that yield undesirable outcomes may elicit guilt (Watson and Spence 2007). Feelings of guilt can occur in social isolation as well as in social contexts. Guilt is likely to result from social appraisal, as it tends to arise in interpersonal relationships (Baumeister et al. 1995). Interpersonal guilt can also arise when a person takes the agency for her or his actions that caused harm to valued partners in close relationships and feels empathetic concern for it (Etxebarria 2000).

Contrasting guilt to shame, Tangney (2003) reminded that guilt involves a negative evaluation of a specific behavior, not the global self and it appears to be the more adaptive emotion, benefiting relationships in a variety of ways. Yet, in some cases, guilt can be disadaptative and can lessen self-esteem (Etxebarria 2000; Burnett and Lunsford 1994). Guilt informs individuals that they have violated intra and interpersonal or social standards and motivates reparative action by, for instance, altering subsequent behavior (Dahl et al. 2003, 2005; Baumeister et al. 1995; Yi and Baumgartner 2004).

Feelings of guilt are likely to occur, especially, when the negative experience is attributed to self. Agency (including both responsibility and control) should be differentiated from focus of guilt. The causal agent is who or what had control over the stimulus event (Watson and Spence 2007). Self-caused undesirable events elicit guilt. Outcomes of the undesirable event can affect the decision maker him/herself and/or other people. Burnett and Lunsford (1994) proposed that it is important to understand toward whom the guilt is directed, because the focus of the guilt may affect the salience of the emotion.

Committing a transgression and thus, violating normative or moral standards, such as indulging in vices, results in increased feelings of guilt. Likewise, moving away from the goal by omission of an act, such as failing to buy a non-virtuous but desired product due to the over-control, may also lead to feelings of missing out in life (Keinan and Kivetz 2008). 


\subsection{Dimensions of Consumer Guilt}

Considering the time period in which the feelings of guilt occurred, i.e. state of guilt, consumer guilt is categorized as anticipatory, reactive and proceeding guilt. Anticipatory guilt is experienced as one contemplates a transgression. The majority of guilt ads have anticipatory guilt appeal (Burnett and Lunsford 1994; Huhmann and Brotherton 1997). Reactive guilt can occur after one has committed a transgression. Proceeding guilt occurs at the point of buying (Lin and Xia 2009). Individuals may also experience existential guilt as a result of the awareness of a discrepancy between one's well-being and the well-being of others (Huhmann and Brotherton 1997).

\subsection{Emotional Constructs Of Consumer Guilt}

Elison (2005) warned that assuming guilt to be a single emotion is a problematic example of cognitive closure, since multiple affects are associated with the state of guilt and varieties of guilt should be distinguished whenever possible. Guilt is often associated with other negative emotions: people may react to their own feeling of guilt with sadness (Soscia 2007). In fact, emotions interact with each other: one emotion may activate, amplify, or attenuate another.

Several researchers conceptualized consumer guilt as a multidimensional construct. However, emotional constructs researched in several studies vary. Lascu (1991) referred guilt to a painful experience of regret, remorse, self blame and self-punishment. Huhmann and Brotherton (1997) defined it "as an emotional state involving penitence, remorse, self-blame and self-punishment. Dahl et al. (2003) associated guilt with feelings of remorse, regret and empathic concern. Bonsu and Main (2006) proposed that it comprises regret, self blame and self-control failure. They also proposed that it indicates a strong sense of self-awareness that enhances a consumer's sense of self-inadequacy. Lin and Xia (2009) identified six emotional constructs of consumer guilt: hesitation, fear, scruple, reluctance to spend, regret, blame. They proposed that while hesitation is the major construct of anticipatory guilt, reluctance to spend is mostly associated with proceeding guilt and regret and blame with reactive guilt.

Despite the widespread acknowledge that guilt is a multi-dimensional construct, several researches chose to concentrate on one or more, yet rarely on all constructs. Among them, regret and remorse took highest attention. Regret is a comparison-based emotion of self-blame, experienced when a non-chosen alternative is known (or is imagined) to yield better outcomes than the chosen one (Bagozzi et al. 2000; Yi and Baumgartner 2004; Zeelenberg and Pieters 2007a; Tsiros and Mittal 2000). Although generally it is accepted that regret is intrinsically aversive and the consumer refrains from repeating the transgression (Etxebarria 2000; Baumeister et al. 1995), Saffrey et al. (2008) found that people value their regret experience in absolute and relative senses (as compared to other commonly experienced negative emotions).

Remorse is similar to regret as it is focused on the action, nevertheless it is different as it occurs in an ethical and societal context; it is concerned with right versus wrong action (Ben Ze'ev 2000). Remorse elicits societal shame, humiliation and anger. Compulsive 
consumers are supposed to exhibit higher degree of remorse after shopping (O'Guinn and Faber 1989; Faber 2000). Indulgences are thought to lead to remorse (Ramanathan and Williams 2007). In a study about consumers' ethical decision-making, remorse is found to be most heavily item loaded in the guilt factor (Steenhaut and van Kenhove 2006).

\subsection{Self-control and balance}

There is a growing body of concern on the relations between (experienced and/or anticipated) self-control failure and regret (e.g., Keinan and Kivetz 2008; Kivetz and Simonson 2002; Chun et al. 2007; Rook 1987; Xu and Schwarz 2009). Self-control refers to capacity to alter its own states and responses and represents the capacity to resist temptations that are likely to be regretted later (Baumeister 2002). Failure in selfcontrol can result in heightened feelings of guilt which in turn help consumers seize an opportunity to regain control and reach to a balanced state, for instance after an indulgence, consumers, subsequently, can make utilitarian choices versus hedonic ones (Ramanathan and Williams 2007). Anticipating regret is found also to facilitate self-control (Keinan and Kivetz 2008), but, as Chun et al. (2007) argued, only for those consumers who need it least. Over-control and excessive farsightedness can also lead to feeling of missing out as well (Kivetz and Keinan 2006). Embracing a time perspective, Keinan and Kivetz (2008) found though in the short-term consumers prefer acting responsibly, over time such controlled behavior generates increasing regret. Moreover, they propose that the passage of time relieve regret about choosing vices, such as hedonic luxuries and intensifies regret about choosing virtue because of the decay of guilt of indulgence and the intensification of feeling of missing out on the pleasures of life.

\subsection{Hedonic consumption desires and indulgence}

Hedonic consumption, defined as multisensory, fantasy and emotive aspects of one's experience with products (Hirschman and Holbrook 1982), is suggested to provide people with experiential enjoyment, satisfying both psychological and physiological needs that necessities may not meet (Xu and Schwarz 2009). In addition to pleasure, Saldanha and Williams (2008) found that consumers simultaneously perceive negative sides of it and feel guilty. Following desires, indulging in luxury items, impulsive and compulsive urges to buy something are perceived to cause feelings of guilt or at least ambivalence. Although it is generally accepted that self-control failures antecedes indulgences and/ or urges to buy something, to avoid the feeling of missing out on the pleasures of life in the long run, consumers can intentionally seek gratification of their desires (Kivetz and Keinan 2006).

Although, findings of several studies indicate that consumers are more likely to consume hedonic goods when they can justify their decisions (e.g. Okada 2005), they can also indulge without any reason. Studies about desires also indicate that consumers perceive desire as exciting, tempting and dangerous and fear of being without desire (Belk et al. 2003). Intensity of feelings of guilt due to the transgression can vary in each situation (Xu and Schwarz 2009). 


\subsection{Coping with Consumer Guilt}

It is generally assumed that consumers are regret-averse in most cases and try to avoid and regulate their regrets (Zeelenberg and Pieters 2007a). They manage stressful emotional experiences in purchase-related situations by means of problem-focused coping and emotion-focused coping strategies In problem-focused coping, consumer tries to manage the source of a negative emotional experience and act on the threat to reduce or avoid it; in emotion-focused coping, consumer tries to manage the emotions experienced as a result of a stressful situation by changing the meaning of the event or regulating the expression of the emotion (Yi and Baumgartner 2004). They are also labeled as behavioral and cognitive coping (Roese et al. 2007).

In their Regret Regulation Theory, Zeelenberg and Pieters (2007b) identified four regret regulation strategies; goal-, decision-, alternative-, or feeling-focused that are implemented based on their accessibility and their instrumentality to the current goal. Goalfocused regret management strategy includes decreasing goal level. Decision-focused strategy includes undoing or reversing, justifying the decision that led to the regretted consequences or denying responsibility for it. Consumer can also switch to alternative or re-appraise quality of alternative. Employing feeling-focused strategies, consumer can engage themselves in psychological repair work or suppress or deny regret (Zeelenberg and Pieters 2007a). In a study about how consumers react to guilt, it is found that engaging in reparative, compensatory actions or making promises or plans regarding future actions were the most frequently employed actions (Dahl et al. 2003).

Among all these strategies, justification has attracted the highest level of attention from researchers (e.g. Connolly and Zeelenberg 2002; Xu and Schwarz 2009; Kivetz and Keinan 2006; Keinan and Kivetz 2008; Kivetz and Simonson 2002). As Okada (2005) observes, consumers are more likely to consume hedonic goods when the decision context allows them the flexibility to justify the consumption. To get pleasure from experiential enjoyment and not feel guilty, consumers try to construct reasons for justification. Marketers can offer consumers these reasons, for example, by means of marketing communications and mixed indulgences (Saldanha and Williams 2008), i.e. hedonic goods with added utilitarian attributes or bundled donations to social causes.

\section{A Qualitative Study: Methodology}

The present study aims to develop a phenomenological account of consumer guilt and broaden the understanding of the dimensions and dynamics of consumer guilt by using in-depth interviews and projective data. It also differs from other studies by its phenomenological approach without any prior engagement in specific propositions. Furthermore, to our best knowledge, this is the first study on consumer guilt in Turkey, a developing, yet less affluent country. Izmir, Turkey's third most populous city is chosen as the field of the study. As an exemplar of westernized Turkish consumer culture, the cultural context of Izmir provides a rich source for data collection. Embracing a diverse population with various ethnic and religious backgrounds of inhabitants, Izmir is mostly known for its westernized consumptionscape. 
Since in consumer culture values and norms of consumers are identified along with consumption, one can expect to find low levels of guilt due to the transgression of social norms and values. Our interpretation is drawn primarily from qualitative data generated by projective collage exercises and nondirective depth interviews of twenty-two consumers. Informants were informed of the purpose of the study and of the confidentiality of their responses. The interviews generally lasted between one and one and a half hour. The participants were aged between 23 and 58 years (with an average of 31) and from different social milieu. Half of them were male. The majority had middle level income. So as to incorporate a rich amalgam of consumer guilt experiences, participants with better and poorer financial means are both incorporated into the sample. The sex (M, F) and age of informants were quoted in reported excerpts.

\section{Findings}

Consumer guilt is found to be regarded as a discomforting emotion that entails multiple emotional constructs. It is comprised of hesitation, sadness, reluctance to spend, regret and self-blame parallel to Lin and Xia's (2009) findings. The findings also support proposition that scruple and reluctance to spend are experienced during the purchasing process. Hesitation was found to relate to anticipatory guilt and regret and self-blame to reactive guilt. While feelings of regret dominantly prevail in the data, remorse is not reported. Even, in the case of an informant who exhibit compulsivity in terms of his motorcycle usage/purchase and, indeed, physically harmed himself previously, his feeling of guilt appear to be only temporarily and not so deep that one can call it remorse. This finding conflicts with suggestions that consumer guilt involves remorse (Lascu 1991; Huhmann and Brotherton 1997; Dahl et al. 2003). Additionally, in the context of consumer culture in Izmir/Turkey, the general suggestion impulsive and compulsive consumer behavior lead to remorse is not supported.

Furthermore, guilt due to the violation of societal standards is only rarely reported. An informant (M, 34) explained that in his constant search for a personal scent, he could not resist buying imitations of well-known perfume brands although he was aware that it harms producers. An older informant (F, 58) expressed her feelings of guilt due to wearing fur. She said, 'Every time I put it on, I think that it was a living animal once. And I just use it for my luxury.' When probed how they feel about societal inequality, middle and higher income-earning informants argue that despite they see poverty as upsetting, they do not need to change the way they live, because poverty is seen "a matter of societal balance" and "people should manage to live on financial resources available to them". Only a few of them explained how they abstained from showing off among less affluent people.

The data include only a few cases that indicate interpersonal guilt. A female informant's (24) explanations of "severe guilt" relate to one occasion when she forced her mother to buy her a pair of boots which she cannot wear comfortably. Another instance is about a working mother's guilt because of her purchases of toys as a compensation for her inability to be at home and take care of her son. She regrets buying entertaining toys 
instead of educational ones. Despite the entertaining toys she purchased did not cause any obvious harm to her son, she felt that she failed in taking good care of him.

Considering the findings about remorse, social-responsibility and interpersonal guilt and observations that guilt feelings are only short-lived and superficial and mostly experienced as a result of good and bad actions but not right versus wrong actions, one can propose that in the context of Izmir/Turkey's consumer culture, personalized value systems outweigh the societal ones. This proposal is consistent with the idea that, in consumer cultures, instead of traditional bases of sociality which are worn away by globalization and postindustrial socioeconomic transformation, individualistic values, such as quest for personal distinctiveness and autonomy in lifestyle choices, are pursued (Arnould and Thompson 2005).

\subsection{Regret of action and inaction}

Regret appears to be the most frequently experienced emotional construct. Informants regret due to action or inaction. Regrets of action evidently prevail in the data. Regrets of purchase of utilitarian products occur associated with a perception of value; purchase of products that are expensive or very cheap, infrequently used, surplus, of low utility, quickly consumed, rapidly outdated/outmoded and unable to meet expectations are explained to cause reactive consumer regret. Purchase of hedonic products cause guilt feeling associated with a perception of transgression.

"I feel negative emotions. I ask myself the question; 'why have I bought this? There was an alternative, was it worth it?" (F, 23)

Regrets of inaction are found to be more likely to be activated when the individual has suffered a promotion failure, as suggested by Roese et al. (2007). As explained by one informant, talking about his collage:

"When I was abroad, I saw a guitar at a very good price. I haven't bought it because I didn't want to take financial risk. But I can't stop thinking about it now. I regret my decision dearly.” (M, 32)

"I chose the picture of an anti-hair loss product. If only I had used it at the time when my hair loss problem has begun, probably I wouldn’t have a problem at all. I regret not buying that product then." $(\mathrm{M}, 31)$

Regret of inaction can occur because of decisions that end up not only in missed opportunities, but also in unfulfilled needs. The data imply that failure to reach the desired positive state can be attributed internally or externally. An interesting finding, however, is that although several informants had no agency (responsibility and control) in the event, they explained their regrets. Consistent with Elison's (2005) suggestion that multiple affects are associated with the state of guilt, they suffer problems of ambivalence and feel sadness associated with regret. For instance, a female informant explains her collage:

"I feel the most intense regret about shoe purchases; my feet are so small that I cannot find fitting shoes." (F, 24) 
Failing to reach a desired positive state creates regret, still, the context in which the consumer experiences regret do actually matter. Less affluent consumers expressed their sadness and regret of their inactions because of the lack of their financial resources. They have no agency in the guilt state they reported as well.

"I am a mother; I regret that I couldn't take a picture of myself during pregnancy. I wish I could have... Like all other women, I like cosmetics. I want to be beautiful. I regret that I cannot buy any; we don't have enough money. When I fail to access them, I feel regret and sadness. That's okay, we still thank god because we are nevertheless healthy." (F, 34)

Regret of inaction is also felt when consumers perceive self-product incongruence, yet, still desire the product. Especially for male informants, who have a heightened concern about the nature of their public image, the appropriateness of purchase of female sextyped product is an important concern.

“One shall use anti-aging creams after the age of 30. I'm at these ages, but I feel ashamed to buy them. Like an old person or a girl, walking around her hands full of creams. I couldn't buy it. If only nobody noticed, I would buy it.” (M, 30)

"I look at kitchen appliances wherever I go. I don't want to be misunderstood by people around me; kitchen is feminine. I regret that I cannot buy one.” (M 25)

\subsection{Transgression of norms}

As described by an informant, transgressing norms evokes guilt feelings, depending on the social context, 'I have specific criteria. I constantly feel guilty when I cannot attain them.' (M, 31). Norms that are reported as being violated can be determined by the consumer him/herself or by others and are product or purchase-situation related. For example, during the buying process of high-involvement products, buying on impulse or without seeking advice from reference groups is referred to as violation of internal norms. This finding also supports the proposition of Loraas and Wolfe (1987), that in the case of a powerful external referent, subjective norms appear to crowd out intrinsic responses and they dominate the decision to learn a new use of technology.

"I feel guilty when I buy electronics and computer items without getting advice from someone who knows those things." (F, 24)

In another instance, an informant explained her confusion between internal and external norms. Here, since she could not achieve her motherhood norms, she tried to compensate it by means of toys and overcome her guilt feelings. In time, she realized external norms about toys and education, she felt regret once more.

"I am a working mother. I repeatedly bought toys for my son for relieving my remorse. I thought he could fill in the gap of my absence. Now I regret it. I wish I would have bought toys not only for amusement, but also for education." (F, 34)

Transgression can be experienced as going out of boundaries set by external sources. An informant (F, 24) explained how guilty she feels because she still lives on allowance and she should spend less. That feeling, however, put pressure on her and she kept on 
shopping. Here, guilt feelings are experienced with several other feelings.

External norms that lead to feelings of guilt when transgressed can be exemplified as 'forgetting to buy a gift for mother on mother's day' (M, 29). Another example is as follows;

"I want to play tennis to get a distinguished position in society. I work at an international corporation. Since I am a member of a particular group, I think I should play tennis. I mostly value the impression it makes and think of visual side of it. That makes me feel guilty." (M, 30)

\subsection{Self-control failure}

Baumeister (2002) proposed that conflicting goals and standards undermine self-control. Emotional fluctuations, desires, impulsive and compulsive urges are found to play a role in conflictions between goals and standards. Emotional distress and desires can change consumer's perception of ideal and actual states, prompt new goals and motivations and contribute to breakdowns in self-control. When people are upset, the goal of feeling better through consumption outweigh other self-regulatory goals. Desired state can be altered with new goals, such as renovation. Tension arises when goals are transient and contributes to a failure in to keep track of (monitor) consumer's own behavior.

"When I feel bad, I go shopping and buy unnecessary or expensive products. Afterwards I regret it, but during shopping, I feel happy. I want instant gratification. I make changes in that way." (F, 28)

"When I am depressed, I find myself walking in malls and that relaxes me. I find myself looking at technology products. I feel regret when I buy on impulse to calm myself down.” (M, 39)

"I shop for my renewal needs. I make mistakes in these periods; I feel like I have so much money that I want to spend it.” $(\mathrm{M}, 30)$

Self-control failures are found to arise due to consumer's failure self-monitoring capabilities (Cervone et al. 2006). As Baumeister (2002) suggested, indulgences ad impulsive purchases are more likely when people fail in keeping track of their behavior and expenditures.

"I realized that when I spend too much I drag myself into financial trouble. Sometimes I can't restrict my desire for things that are actually unnecessary and thus get myself into debt. When I find myself in a situation that I can't buy something else I really want, I feel guilty."'(M, 39)

External sources also affect self-monitoring capabilities; pictures of credit cards, especially, are shown as the most seducing source in collage exercises. Other sources mentioned by the informants are shopping malls, installment sales, advertisements and salespersons.

"Fashion and skin care products make me feel guilty. Producers keep launching new products. Salespersons are very persuasive, you end up buying products that aren't 
even appropriate for your skin type. You begin to feel guilt even when you are in your way to the cashier. You begin to question your need. But at that moment, they really attracted you." (F, 23)

Bernthal et al. (2005) acknowledged the power of credit cards to command other consumption markers of a desired lifestyle and revealed that they facilitate coping with debt-imposed constraints on lifestyle achievements and movement among lifestyle spaces within the marketplace. Nevertheless, failure in controlling card usage can trigger rapid debt accumulation and a loss of mobility within the marketplace. Norum (2008) also indicated that compulsive buyers engage in uncontrolled credit card purchases and thus, suffer feelings of fear, anxiety of guilt. Several informants explicitly pointed to their self-control and self-monitoring problems activated by their credit cards usage practices.

"Credit card is the product that makes me feel extremely guilty. I get happy when I spend all the money available. I use credit cards unconsciously and later I regret it. I want to buy everything I see." (F, 53)

In Turkey, banks facilitate buying in installments through credit cards. Although it gives consumers more opportunities to reach their desired lifestyle, it also entails a danger of monitoring purchase practices and loosing track of expenditures.

"I feel guilty because of my credit card usage. In magazine advertisements, they say that they prolong installments for additional six months. I feel as if I can buy that brand I desire. Later, yet, I regret again." (F, 23)

"The picture of a credit card gives rise to my feeling of regret. Even during shopping with a credit card, I think that I won't be able to pay later. I feel very bad when the payment time comes, because every time the amount is above my expectations. I buy in installments, but then I don't realize that they accumulate." (F, 34)

Baumeister (2002) suggested that self-control also includes a person's capacity to alter the self; a person might know what he/she wants and be quite aware of his or her own behavior but not be able to make the self perform the necessary actions. The first quotation below reveals for the cyclic nature of guilt feelings that arise because of weakness in capacity to alter the causative behavior. In the second quotation below, consistent with work on justification (e.g. Okada 2005; Kivetz and Keinan 2006; Keinan and Kivetz 2008; Xu and Schwarz 2009), one can see how perceptions of time period influence attitudes toward hedonic consumption; anticipating long-term regret provides reasons for justification of relaxing self-control so as to avoid feelings of missing out on the hedonic pleasures.

"My efforts to change my behavior [which causes guilt feelings] is only temporarily and don't last that long. Soon after, I continue buying those products." (F, 28)

"I set quotas for myself so that I won't use my credit card. When I come across the products that I just can't give up, my restriction eases. Then I blame myself for behaving in a similar manner. I justify my behavior by thinking that I can't find that kind of a product I like so much once again." (F, 34) 
Parallel Keinan and Kivetz's (2008) findings, over-control is found to produce long-term regret feelings. Informants experienced over-control based on the context, yet individual differences in self-control also support the idea that they can also form a seemingly stable aspect of personality (Baumeister 2002). Collage work of a female informant, at age of 23, is comprised of products that she couldn't buy due to her over-control disposition.

"I don't want to buy expensive items. I fear that something bad can happen when I buy really high-priced products. My regret feelings are elevated when they come apart. In electronics, I think just the opposite; I think that I should pay more just for the case they might break down." (F, 23)

\subsection{Hedonic consumption, desire and indulgence}

Consistent with work on desires and hedonic consumption (e.g. Belk et al. 2003; Dedeoğlu and Savasci 2005; Ramanathan and Williams 2007; Saldanha and Williams 2008), indulgence of desires is seen as a source of consumer guilt. Belk et al. (2003) demonstrated that consumer desire is a passion born between consumption fantasies and social situational contexts. Even imaginations are found to generate guilt feelings.

"First picture in my collage shows a nice lady under a headline "perfect skin". Whenever I see these pictures I think of myself and imagine my skin in such a condition. I wish it was. I want to use that kind of products, but I feel guilty about that. Quality products are so expensive. Yet these pictures fascinate me.” (F, 25)

Yielding to hedonic temptations and indulging in luxury is viewed as wasteful. A male informant explained that he feels guilty even when the price of a luxury item is paid by another person. On the other hand, ambivalent feelings are likely to occur during hedonic consumption. Consistent with Virvilaite's et al. (2009) findings, following quotations reveal that in addition to feelings of guilt, hedonic products also deliver pleasure. Valence and intensity of both can vary contextually. Second passage below reveals that lower affluent informants are found to suffer from severe ambivalence between pleasure and guilt.

"I feel guilty when I choose luxury products over cheap ones. But I also feel so happy when I use it in company of my more affluent friends.” (M, 30)

"I experience mixed feelings of guilt and pleasure. We felt very happy when we bought a hair dryer. After we came home, I felt so regretful. We needed it, but we could have bought a smaller one. We didn't return it and I don't feel regretful anymore." (F, 34)

Desire objects that offer magical means for transformation and belonging appear to be sources of guilt feelings, especially when consumers realize that they do not automatically facilitate transformation and belonging. Informants explained how they regret buying a premium brand that offers exclusivity, yet is bought by masses, fashion brands that fail to construct a personal style or cosmetic products that fail to deliver their magical promises. 
"Converse has become an ordinary brand. I put them on because they are comfortable. But a kind of guilt comes up, because everybody owns one." (F, 25)

"Ads use such influential arguments so that one may think that they make magic happen. But that's not what happens. I bought a skin care product once and paid a lot. I used it for a month. I kept it for one year and then I threw it away. I felt so guilty. I lost my faith." (F, 34)

Impulsive buying can be defined as a response to a compelling urge or desire to buy something without any previous intention and then acting on it without thoroughly considering whether the purchase is consistent with one's goals and plans (Baumeister 2002; MacInnis and Patrick 2006). An informant's explanation of his collage work exemplifies that guilt feelings may arise subsequently.

"The product that makes me feel most guilty is the automobile. Two years ago, I bought one on a sudden impulse without any deliberation on its country of production and brand. Every time I drive it, I ask myself why I have bought it in the first place. I'm not sure, I still wonder about my reasons." (M, 30)

Compulsive buying includes repetitive purchasing resulting from a chronic loss of impulse control that will ultimately cause harm to the individual and/or others' (O'Guinn and Faber 1989). Consequences of it are more severe compared to those of impulsive buying and includes severe financial problems, guilt feelings, lowered self-esteem and a harmful impact on interpersonal relationships.

"I bought a motorcycle that has such a high-speed capacity. After my last accident, I promised myself not to speed anymore. Every time I promise not to, but I do it again. I saw a camera the other day and didn't buy it. But I can buy it soon. My mind is still there, I can't do anything. I can't even work. Eventually, it generally doesn't perform as I dreamed." (M, 30)

It is also observed that guilt feelings are likely to occur in a context that consumers, in a quest for constructing narratives of identity, 'pursue personally edifying goals through the consumer positions that the market produces' (Arnould and Thompson 2005).

"I believe that I have to have an everyday perfume, so I am constantly searching for one and spend too much. By buying a perfume twice, I spend as much as the minimum wage. Spending so much just to construct an image bothers me." (M, 34)

\subsection{Coping with consumer guilt}

Consistent with work on the coping mechanism cited above, the data of the present study provide strong evidence for justification. While more affluent informants mostly justify their purchases on impulsivity and/or compulsivity, middle-income earning informants try to justify theirs on their hedonic temptations. Data of lower affluent informants reveal that they also need to justify even their utilitarian purchase. Informants explained how they create justifications for decisions that they are motivated to make, as Okada (2005) suggested. A male informant, at age of 38, justifies his decision by thinking that buying in installments enables him to divide his regrets over several months. 
"I try to make a just decision and try to develop a defense mechanism about my reason of purchasing that product. I know I'm wrong, yet I try to find out some points for excusing myself. However, I don't get rid of that feeling, every time I see the product I recall it." $(\mathrm{M}, 30)$

"We are mortals after all, getting depressed about shopping won't do any good. I worked for years and earned my retirement. I don’t need anybody. I calm by saying that can be my luxury." (F, 58)

In order to cope with consumer guilt, consumers can also engage in reparative and compensatory actions. It is observed that consumers cope with reactive guilt by returning the product, using the product to a degree or extent higher than one normally does or finding new utilization ways. In case of proceeding guilt, consumers end up changing their purchase decision before the transaction.

On the other hand, the data did not provide any solid evidence to assure that guilt leads to self-punishment. A few informants' reparative action of "leaving credit card at home", just for a short-lived time period, can be regarded a softer reparative action compared to self-punishment. Informants reported that they make promises or plans regarding future actions or postpone the transgression due to anticipated regret. Fifty-eight years old female informant reported although she wants to buy many skin products, she tries to define them as a luxury and satisfy herself with those at hand. Setting quotas is reported as another option. Informants also reported that they engage themselves in psychological repair work, such as comforting themselves by personal suggestions and convincing themselves, for example, that they learned a lesson, or suppressing or denying regret.

"I talk to myself and blame myself for my bad decision. After a while my daughters or a reasonable person says "that's enough", I think that I overreacted." (F, 53)

External attribution and escapism are among other reactions. The motorcycle-owner informant chose to blame his friend for not holding him back from buying a new one after his last accident. Informants also explained how they blame brand, company and/ or salesperson. That kind of an attribution can influence marketers negatively, especially when consumers generalize negative affect to their total encounter with the brand and company and develop negative attitude. It is also observed that consumers are also inclined to ignore or hide the outcome and escape from it. Most informants chose to keep their regrets in private. Exposing their regret to their environment is supposed to make the negative outcomes of their decision and, hence, the feeling real. Another informant explained how he tries to escape from the outcomes of his bad decision;

"I regret buying Ford due to its high fuel-consumption and decreasing market price. When I want to go out, I ponder so much about driving it. Since it will make me feel guilty again, I don't want to drive it. I even abstain from going out." (M, 27)

Although Zeelenberg and Pieters (2007b) made distinctions between four regret regulation strategies (goal-, decision-, alternative-, or feeling-focused strategies), it is not always possible to isolate them from each other. For example justification is often reported with psychological repair work. 


\section{Conclusions and Discussions}

The findings reveal that consumer guilt is a discomforting and aversive emotion that entails multiple emotional constructs. Parallel to Lin and Xia (2009)'s findings, the constructs that are found to be relevant in the present study are hesitation, sadness, reluctance to spend, regret and self-blame. Feelings of regret dominantly prevail in the data. However, different from other studies (e.g. Lascu 1991; Huhmann and Brotherton 1997; Dahl et al. 2003; Baumeister et al. 1995), remorse, social-responsibility and interpersonal guilt are only rarely reported in the study. Additionally, in the context of consumer culture in Izmir/Turkey, the general suggestion that impulsive and compulsive consumer behavior lead to remorse is not supported. Furthermore, guilt feelings are found to be short-lived and superficial and mostly arise as a result of good and bad actions but not always of right versus wrong actions. These findings allow us to propose that in the context of Izmir/Turkey's consumer culture, personalized value systems outweigh the societal ones. This proposal is consistent with the idea that, in consumer cultures, instead of traditional bases of sociality which are worn away by globalization and postindustrial socioeconomic transformation, individualistic values, such as quest for personal distinctiveness and autonomy in lifestyle choices, are pursued (Arnould and Thompson 2005).

Contrary to the common suggestion that, in the consumption society, guilt feelings have gone away, the findings supports O'Shaughnessy and O'Shaughnessy's (2002) argument that emotions, just like shame and guilt, simply get attached to new concerns brought about by cultural drift. Etxebarria (2000) remarked that guilt feelings reveal a strong socio-cultural influence and not the intensity of guilt feelings, but events that cause guilt can differ in different groups as a result of socialization, the influence of different cultural values and conception of self depending on different modernities. Considering that consumer guilt feelings may depend on cultural and historical context, one can anticipate diversities in consumers' experiences of feelings of guilt.

The data imply that imbalanced emotional state resulting from transgression of personal and socio-cultural norms, self-control failure and indulgence in desires and hedonic consumption can cause feelings of guilt. Regrets of action evidently prevail in the data. Regrets of purchase of utilitarian products occur associated with a perception of value, while purchase of hedonic products cause feeling of guilt associated mostly with perceptions of transgression and loss of self-control. Regret of inaction can occur when consumer's decisions end up in a failure of desired state, i.e. in missed opportunities and unfulfilled needs. Besides, context in which the consumer experiences regret do actually matter. Less affluent consumers' feelings of sadness and regret of their inactions because of their lack of financial resources indicate their suffering of ambivalence. Since they have no agency in the guilt state reported, one can assume that they cannot isolate their feelings of sadness from regret. Hence, one can suggest that multiple affects are associated with the state of guilt. Regret of inaction is also felt when consumers perceive self-product incongruence, yet still desire the product.

Self-control failure appears to be a main cause of heightened guilt-feelings. Emotional 
fluctuations, desires, impulsive and compulsive urges are found to play role in conflictions between goals and standards. Tension arises when goals are transient and contributes to a failure in to keep track of (monitor) consumer's own behavior. Consistent with work on self-control (e.g. Baumeister 2002; Cervone et al. 2006), self-control failures that cause guilt feelings are also found to arise due to consumer's failure selfmonitoring capabilities and a person's capacity to alter the self. External sources are found to affect self-monitoring capabilities. Among other sources, such as shopping malls, installment sales, advertisements and salespersons, credit cards are found as the most seducing. Although it gives consumers opportunities to reach their desired lifestyle, it also entails a danger of monitoring purchase practices and loosing track of expenditures. The findings support Bernthal's et al. (2005) suggestions that credit cards are powerful in commanding other consumption markers of a desired lifestyle and facilitating mechanisms of coping with debt-imposed constraints on lifestyle achievements and movement among lifestyle spaces within the marketplace. Nevertheless, failure in controlling credit card usage can trigger rapid debt accumulation and a loss of mobility within the marketplace.

Broadening the scope of the argument that all pleasurable emotions tend to be shortlived in a consumer culture (O'Shaughnessy and O'Shaughnessy 2002), one can say that unpleasant negative emotions, guilt feelings in the current case, are also short-lived. The data provides proof for the cyclic nature of guilt feelings that arise because of weakness in capacity to alter the causative behavior. Moreover, consistent with work on justification (e.g. Okada 2005; Kivetz and Keinan 2006; Keinan and Kivetz 2008; Xu and Schwarz 2009), it is found that perception of time period influence attitudes toward hedonic consumption; anticipating long-term regret provides reasons for justification of relaxing self-control so as to avoid feelings of missing out on the hedonic pleasures. Parallel Keinan and Kivetz's (2008) findings, it is found that over-control may cause long-term regret, yet individual differences in self-control also support the idea that they can also form a seemingly stable aspect of personality (Baumeister 2002).

Consistent with the research on impulsive and compulsive buying and desires (e.g. Belk et al. 2003; MacInnis and Patrick 2006; O'Guinn and Faber 1989), the present study also demonstrated how indulgence in desires cause guilt. Even imagination is found to generate guilt feelings. Ambivalent feelings are likely to occur during hedonic consumption, in addition to feeling of guilt, hedonic products also deliver pleasure. Desire objects that offer magical means for transformation and belonging appear to be sources of guilt, especially when consumers realize that they in fact do not automatically facilitate transformation and belonging. It is also observed that guilt feelings are likely to occur in a context that consumers, in a quest for constructing narratives of identity, 'pursue personally edifying goals through the consumer positions that the market produces' (Arnould and Thompson 2005).

Among coping mechanisms stated in relevant literature (e.g. Connolly and Zeelenberg 2002; Xu and Schwarz 2009; Kivetz and Simonson 2002; Okada 2005; Zeelenberg and Pieters 2007b; Yi and Baumgartner 2004), the data entails strong evidence for justification. While more affluent informants mostly justify their purchases on impulsivity and/ 
or compulsivity, middle-income earning informants try to justify theirs on their hedonic temptations and lower affluent informants justify even their utilitarian purchases. The data did not provide solid evidence to assure that guilt leads to self-punishment. One can propose that a few informants' reparative action of "leaving credit card at home", just for a short time period, cannot be regarded self-punishment. The present study shows how consumers make promises or plans regarding future actions or postpone the transgression due to anticipated regret. It is found that consumers are likely to decrease goal level, set quotas, engage themselves in psychological repair work or in escapism, or attribute the responsibility toward others for coping with consumer guilt. One can suggest that, it is not always possible to isolate four types of regret regulation strategies (goal, decision, alternative, or feeling-focused strategies), proposed Zeelenberg and Pieters (2007b), from each other. For example justification is often reported with psychological repair work.

The present study represents an attempt to develop a phenomenological account of consumer guilt and broaden the understanding of the dimensions and dynamics of consumer guilt by using in-depth interviews and projective data. Pursuing the aim to explore the construct grounded in consumers' lived experiences, the present study differs from other studies by its phenomenological approach. Furthermore, as far as we know, this is the first study on consumer guilt in Turkey, a developing, yet less affluent country. One limitation of this study may relate to the self-report method used in interviews. Informants may be less willing to report their guilt-inducing behavior that will simultaneously erect shame, embarrassment and humiliation in a societal context. So as to overcome that limitation, projective collage construction is also used as a data collection technique. While the findings are exploratory, they nevertheless offer interesting insights into consumer guilt in the context of a developing country. Several avenues for future research emerge from this study. First, it would be useful to research how consumer's interpretations and experiences of guilt feelings differ in groups with diverse historical and socio-cultural patterns of consumption. Second, the use of guilt appeals in marketing communications can be researched with regard to consumer vulnerability (Melnikas and Smaliukiene 2007). Especially, when guilt appeals are used by advertiser to bring subconscious consumer preferences to the surface (Saee 2005), and to exploit the feelings socially and psychologically vulnerable consumers, some damaging consequences, such as eating disorders and compulsive buying, may be observed. That kind of a study may guide companies in their socially responsible conducts and public policy makers in coping with the dark side of consumer culture. Third, future studies can focus on credit cards that emerged as a very forceful source of consumer guilt feelings.

\section{References}

Arnould, E. J; Price, L. L. 2000. Authenticating acts and authoritative performances: Questing for self and community, in S. Ratneshwar, D. G. Mick, C. Huffman (Eds.). The Why of Consumption: Contemporary Perspectives on Consumers Motives, Goals and Desires. London: Routledge, 140-163.

Arnould, E. J; Thompson, C. J. 2005. Consumer culture theory (CCT): Twenty years of research, Journal of Consumer Research 31(March): 868-882. doi:10.1086/426626 
Bagozzi, R. P.; Baumgartner, H.; Pieters, R.; Zeelenberg, M. 2000. The role of emotions in goaldirected behavior, in S. Ratneshwar, D. G. Mick, C. Huffman (Eds.). The Why of Consumption: Contemporary Perspectives on Consumers Motives, Goals and Desires. London: Routledge, 36-58.

Basil, D. Z.; Ridgway, N. M.; Basil, M. D. 2008. Guilt and giving: A process model of empathy and efficacy, Psychology and Marketing 25(1): 1-23. doi:10.1002/mar.20200

Baumeister, R. F. 2002. Yielding to temptation: self-control failure, impulsive purchasing and consumer behavior, Journal of Consumer Research 28(4): 670-676. doi:10.1086/338209

Baumeister, R. F.; Stillwell, A. M.; Heatherton, T. F. 1995. Personal narratives about guilt: Role in action control and interpersonal relationships, Basic and Applied Social Psychology 17(1/2): 173-198. doi:10.1207/s15324834basp1701\&2_10

Bei, L. T.; Lin, Y. T; Yu, C. M. 2007. The relationship between consumer guilt and shopping behavior, Advances in Consumer Research 34: 405-408.

Belk, R. W.; Ger, G.; Askegaard, S. 2003. The fire of desire: A multisided inquiry into consumer passion, Journal of Consumer Research 30(3): 326-351. doi:10.1086/378613

Ben-Ze'ev, A. 2000. The subtlety of emotions. USA: MIT Press.

Bernthal, M. J.; Crockett, D; Rose, R. L. 2005. Credit cards as lifestyle facilitators, Journal of Consumer Research 32 (1): 130-145. doi:10.1086/429605

Bonsu, S; Main, K. 2006. Consumer guilt: Preliminary construct assessment and scale development, Asia-Pacific Advances in Consumer Research Conference Proceedings 7: 350-351.

Boujbel, L. 2008. Never-ending desires: Assessing consumers' propensity to desire consumption objects, Advances in Consumer Research - European Conference Proceedings 8: 319-324.

Burnett, M. S.; Lunsford, D. A. 1994. Conceptualizing guilt in the consumer decision-making process, Journal of Consumer Marketing 11(3): 33-43. doi:10.1108/07363769410065454

Chang, C. T. 2008. To donate or not to donate? Product characteristics and framing effects of causerelated marketing on consumer purchase behavior, Psychology and Marketing 25(12): 1089-1110. doi:10.1002/mar.20255

Cervone, D.; Shadel, W. G.; Smith, R. E; Fiori, M. 2006. Self-regulation: reminders and suggestions from personality science, Applied Psychology: An International Review 55(3): 333-385. doi:10.1111/j.1464-0597.2006.00261.x

Chun, H.; Patrick, V. M.; MacInnis, D. J. 2007. Making prudent vs. impulsive choices: The role of anticipated shame and guilt on consumer self-control, Advances in Consumer Research - North American Conference Proceedings 34: 715-719.

Connolly, T.; Zeelenberg, M. 2002. Regret in decision making, Current Directions in Psychological Science 11(6): 212-216. doi:10.1111/1467-8721.00203

Cooke, A. D. J.; Meyvis, T.; Schwartz, A. 2001. Avoiding future regret in purchase-timing decisions, Journal of Consumer Research 27(4): 447-459. doi:10.1086/319620

Cotte, J.; Ritchie, R. 2005. Advertisers' theories of consumers: Why use negative emotions to sell? Advances in Consumer Research 32: 24-31.

Cotte, J.; Coulter, R. A; Moore, M. 2005. Enhancing or disrupting guilt: The role of ad credibility and perceived manipulative intent, Journal of Business Research 58(3): 361-368.

doi:10.1016/S0148-2963(03)00102-4

Coulter, R. H.; Cotte, J.; Moore, M. L. 1999. Believe it or not: Persuasion, manipulation and credibility of guilt appeals, Advances in Consumer Research 26: 288-294.

Dahl, D. W.; Honea, H.; Manchanda, R. V. 2003. The nature of self-reported guilt in consumption contexts, Marketing Letters 14(3): 159-171. doi:10.1023/A:1027492516677

Dahl, D. W.; Honea, H.; Manchanda, R.V. 2005. Three Rs of interpersonal consumer guilt: Relation- 
ship, reciprocity, reparation, Journal of Consumer Psychology 15(4): 307-315.

doi:10.1207/s15327663jcp1504_5

Dedeoğlu, O. A.; Savasci, I. 2005. Tüketim kültüründe beden güzelliği ve yemek yeme arzulari: Kadinlarin tüketim pratiklerine yansimasi [Body images and eating desires in consumer culture: Women's consumption practices], Ege Academic Review 5(1-2): 77-88 (in Turkish).

Elison, J. 2005. Shame and guilt: A hundred years of apples and oranges, New Ideas in Psychology 23(1): 5-32. doi:10.1016/j.newideapsych.2005.07.001

Etxebarria, I. 2000. Guilt: An emotion under suspicion, Psicothema 12(Suppl. 1): 101-108.

Faber, R. J. 2000. The urge to buy: A uses and gratifications perspective on compulsive buying, in S. Ratneshwar, D. G. Mick, C. Huffman (Eds.). The Why of Consumption: Contemporary Perspectives on Consumers Motives, Goals and Desires. London: Routledge, 177-196.

Ghingold, M. 1981. Guilt arousing marketing communications: an unexplored variable, Advances in Consumer Research 8: 442-448.

Hassay, D. N.; Smith, M. C. 1996. Compulsive buying: An examination of the consumption motive, Psychology and Marketing 13(8): 741-752.

doi:10.1002/(SICI)1520-6793(199612)13:8<741::AID-MAR2>3.0.CO;2-F

Hirschman, E. C.; Holbrook, M. B. 1982. Hedonic consumption - emerging concepts, methods and propositions, Journal of Marketing 46(3): 92-101. doi:10.2307/1251707

Huhmann, B. A.; Brotherton, T. P. 1997. A content analysis of guilt appeals in popular magazine advertisements, The Journal of Advertising 26(2): 35-45.

Keinan, A.; Kivetz, R. 2008. Remedying hyperopia: The effects of self-control regret on consumer behavior, Journal of Marketing Research 45(6): 676-689. doi:10.1509/jmkr.45.6.676

Kivetz, R.; Keinan, A. 2006. Repenting hyperopia: an analysis of self-control regrets, Journal of Consumer Research 33(2): 273-282. doi:10.1086/506308

Kivetz, R.; Simonson, I. 2002. Self-control for the righteous: toward a theory of precommitment to indulgence, Journal of Consumer Research 29(2): 199-217. doi:10.1086/341571

Lascu, D. N. 1991. Consumer guilt - examining the potential of a new marketing construct, Advances in Consumer Research 18: 290-295.

Lin, Y. T.; Xia, K. N. 2009. The relationship between consumer guilt and product categories, AsiaPacific Advances in Consumer Research 8: 332-333.

Loraas, T.; Wolfe, C. J. 2006. Why wait? Modeling factors that influence the decision of when to learn a new use of technology, Journal of Information Systems 20(2): 1-23. doi:10.2308/jis.2006.20.2.1

MacInnis, D. J.; Patrick, V. M. 2006. Spotlight on affect: Affect and affective forecasting in impulse control, Journal of Consumer Psychology 16(3): 224-231. doi:10.1207/s15327663jcp1603_4

Melnikas, B.; Smaliukiene, R. 2007. Consumer vulnerability in pharmaceutical market: case of Baltic countries, Journal of Business Economics and Management 8(1): 51-62.

Meyvis, T.; Cooke, A. D. J. 2007. Learning from mixed feedback: Anticipation of the future reduces appreciation of the present, Journal of Consumer Research 34(2): 200-211. doi:10.1086/519148

Miller, D. 1995. Consumption as the vanguard of history a polemic by way of an introduction, in D. Miller (Ed.). Acknowledging Consumption, London: Routledge, 1-52.

Mosak, H. H. 1987. Guilt, guilt feelings, regret and repentance, Journal of Individual Psychology: The Journal of Adlerian Theory, Research and Practice 43(3): 288-295.

Norum, P. S. 2008. The role of time preference and credit card usage in compulsive buying behaviour, International Journal of Consumer Studies 32(3): 269-275. doi:10.1111/j.1470-6431.2008.00678.x

O’Guinn, T. C.; Faber, R. J. 1989. Compulsive buying: A phenomenological exploration, Journal of Consumer fResearch 16(2): 147-157. doi:10.1086/209204 
Okada, E. M. 2005. Justification effects on consumer choice of hedonic and utilitarian goods, Journal of Marketing Research 42(1): 43-53. doi:10.1509/jmkr.42.1.43.56889

O'Shaughnessy, J.; O'Shaughnessy, N. J. 2002. Marketing, the consumer society and hedonism, European Journal of Marketing 36(5/6): 524-547. doi:10.1108/03090560210422871

Puri, R. 1996. Measuring and modifying consumer impulsiveness: A cost-benefit accessibility framework, Journal of Consumer Psychology 5(2): 87-113. doi:10.1207/s15327663jcp0502_01

Ramanathan, S.; Williams, P. 2007. Immediate and delayed emotional consequences of indulgence: The moderating influence of personality type on mixed emotions, Journal of Consumer Research 34(2): 212-223. doi:10.1086/519149

Rook, D. W. 1987. The buying impulse, Journal of Consumer Research 14(2): 189-199. doi:10.1086/209105

Roese, N. J.; Summerville, A.; Fessel, F. 2007. Regret and behavior: Comment on Zeelenberg and Pieters, Journal of Consumer Psychology 17: 25-28. doi:10.1207/s15327663jcp1701_5

Saee, J. 2005. Societal ethics and legal system facing contemporary marketing strategies: an Australian insight, Journal of Business Economics and Management 6(4): 189-197.

Saffrey, C.; Summerville, A; Roese, N. J. 2008. Praise for regret: people value regret above other negative emotions, Motivation and Emotion 32(1): 46-54. doi:10.1007/s11031-008-9082-4

Saldanha, N.; Williams, P. 2008. Mixed indulgences: when removing sin may backfire, Advances in Consumer Research 35: 139-140.

Sandikci, O.; Ger, G. 2002. In-between modernities and postmodernities: Theorizing Turkish consumptionscape, Advances in Consumer Research 29: 465-470.

Sengupta, J.; Zhou, R. R. 2007. Understanding impulsive eaters' choice behaviors: The motivational influences of regulatory focus, Journal of Marketing Research 44(2): 297-308.

doi:10.1509/jmkr.44.2.297

Soscia, I. 2007. Gratitude, delight, or guilt: The role of consumers' emotions in predicting postconsumption behaviors, Psychology and Marketing 24(10): 871-894. doi:10.1002/mar.20188

Soscia, I., Busacca, B.; Pitrelli, E. 2008. Guilt decreasing marketing communication: An unexplored appeal, Advances in Consumer Research - European Conference Proceedings 8: 107-108.

Steenhaut, S.; Van Kenhove, P. 2006. The mediating role of anticipated guilt in consumers' ethical decision-making, Journal of Business Ethics 69(3): 269-288. doi:10.1007/s10551-006-9090-9

Tangney, J. P. 2003. Self-relevant emotions, in M. L. Leary, J. P. Tangney (Eds.). Handbook of Self and Identity, USA: The Guilford Press, 384-400.

Thompson, C. J.; Hirschman, E. C. 1995. Understanding the socialized body - a poststructuralist analysis of consumers' self conceptions, body images and self-care practices, Journal of Consumer Research 22(2): 139-153. doi:10.1086/209441

Tsiros, M.; Mittal, V. 2000. Regret: A model of its antecedents and consequences in consumer decision making, Journal of Consumer Research 26(4): 401-417. doi:10.1086/209571

Virvilaite, R.; Saladiene, V.; Bagdonaite, R. 2009. Peculiarities of impulsive purchasing in the market of consumer goods, Inzinerine Ekonomika - Engineering Economics (2): 101-108.

Watson, L.; Spence, M. T 2007. Causes and consequences of emotions on consumer behaviour: A review and integrative cognitive appraisal theory, European Journal of Marketing 41(5/6): 487-511. doi:10.1108/03090560710737570

$\mathrm{Xu}$, J.; Schwarz, N. 2009. Do we really need a reason to indulge? Journal of Marketing Research 46(1): 25-36. doi:10.1509/jmkr.46.1.25

Yi, S.; Baumgartner, H. 2004. Coping with negative emotions in purchase-related situations, Journal of Consumer Psychology 14(3): 303-317. doi:10.1207/s15327663jcp1403_11 
Zeelenberg, M.; Pieters, R. 2007a. A theory of regret regulation 1.0, Journal of Consumer Psychology 17(1): 3-18. doi:10.1207/s15327663jcp1701_3

Zeelenberg, M.; Pieters, R. 2007b. A theory of regret regulation 1.1, Journal of Consumer Psychology 17(1): 29-35. doi:10.1207/s15327663jcp1701_3

\section{VARTOTOJO KALTĖS JAUSMAS: FENOMENOLOGIJOS TYRINĖJIMAS}

\section{A. Ö. Dedeoğlu, İ. Kazançoğlu}

Santrauka

Kaltė ir neramumas - labai paplitusi emocinè būsena, kurią dažnai nagrinèja reklamos specialistai. Nepaisant to, kad apskritai yra atlikta daugybe tyrimų, vis dar trūksta vartotojo kaltès aspektus analizuojančių tyrimų, kurie padètu geriau suvokti šią problemą. Šiame tyrime buvo stengiamasi išplètoti vartotojo kaltès fenomenologiją ir praplèsti suvokimo ribas apie vartotojų kaltès matmenis ir dinamika, grindžiamą vartotojo išgyventa patirtimi, naudojant nuodugnią apklausą ir projektinę informaciją. Atlikus visapusišką analizę, paaiškejo, kad egzistuoja penki vartotojo kaltės matmenys: neryžtingumas, liūdesys, nenoras išlaidauti, apgailestavimas, savęs kaltinimas. Vartotojas jaučia kaltę dèl prasižengimo, savikontrolès praradimo, piktnaudžiavimo, tenkinant hedonistinius troškimus. Rezultatai parodè, kad kaltè jausmas yra cikliškas, trumpalaikis ir paviršutiniškas, dažniausiai kylantis kaip gero ar blogo veiksmo rezultatas. Vartotojiškoje visuomenèje kaltė yra siejama su dẻl kultūros poslinkio atsiradusiais naujais rūpesčiais.

Reikšminiai žodžiai: vartotojo kaltè, prasižengimas, savikontrolès praradimas, atlaidumas, vartotojo kultūra, apgailestavimas, savęs kaltinimas, liūdesys, neryžtingumas.

Ayla ÖZHAN DEDEOĞLU. An Associate Professor of Marketing in the Department of Marketing at Faculty of Economics and Administrative Sciences, Ege University. She received her PhD degree from Dokuz Eylul University in 2001. Her primary interests include sociocultural, experiential, and symbolic aspects of consumption and interpretive strategies of market agents.

İpek KAZANÇOĞLU. An Assistant Professor of Marketing in the Department of Marketing at Faculty of Economics and Administrative Sciences, Ege University. She received her PhD degree from Ege University in 2008. Her research areas include marketing, consumer behaviour, brand management, retailing. 